European biotechnology lies in disarray Commission's plan lacks

\section{friends}

Trouble looms again for the ill-fated European research programme in biomolecular engineering, conceived in 1976 and, after much consultation, proposed to Community states in final form by the European Commission last summer. The Council of Ministers, which has the final authority over such proposals, placed the 116 million (26 million European Units of account (EUA)) fiveyear programme with its research committee for comment. And the committee now says that it cannot agree on the content, scale or cost of the programme.

The proposal was innovative in its time - it was praised by Jacques Monod and has been broadly backed by European industry, but it now looks unlikely to get approval in any form before November, the next date for a Council of Community Research Ministers. If the research committee had agreed, there was a chance that the programme would have gone through as a "point A" - a proposal that can be approved by any council without debate.

The programme deals with potential scientific bottlenecks in enzyme and recombinant DNA technology - such as provision of cofactors in enzyme-induced synthesis, or problems of expression efficiency in genetically engineered bacteria - through "indirect actions", where the Commission selects and organizes groups around Europe to investigate specific questions and pays half the costs (see Nature 283, 125; 1980).

Originally the programme contained six projects, but discussions last year within CREST, a committee of government representatives in which the Commission takes soundings of national views, reduced the number to four, eliminating areas with likely immediate medical or industrial application, and trimmed the budget to 15 million EUA. French representatives requested that half this sum be spent on education and training.

Eventually a "CREST compromise" was worked out, with 4 projects and 15 million EUA of which 20 per cent would be for education. But, at the level of the research committee of council, this compromise has proved unacceptable - as has a further compromise proposed by the secretary of the committee which would reduce the spending still further to 11.8 million EUA. The French members want their 50 per cent education and German members want the number of research projects cut to two, restricting the programme to agricultural applications (basically gene transfer in plants) and safety questions. Britain appears to back the CREST compromise, or something close to it; all other states would have preferred the original proposal but are prepared to accept that of CREST.

In fact the proposal has fallen foul of the two major obstacles to Brussels-initiated research. First, the concept of a "European" industry benefiting the Community as a whole has not yet taken root, and if a piece of research has a potentially large economic benefit - such as research into cloning vectors, one of the original six proposals - nations are unwilling to share their expertise. The French view of the biomolecular engineering programme exemplifies this attitude: the government wishes the programme to be reduced to a training programme in recombinant DNA techniques (it has had trouble recruiting for its genetic engineering company, Transgene) and effectively rejects the idea of joint research.

The second objection to Brussels-based work is that if nations already have a research programme in a particular area, they are unlikely to set aside funds in that area for work undertaken outside their control. This is broadly the position of German biotechnologists: they have a large national programme, but research money is tight, and contributing to a Commissionbased programme would only distort their priorities.

More Community-minded biotechnologists in both France and Germany, however, point out that long-term progress

\title{
German physics in row about Einstein
}

The German Physical Society (Deutsche Physikalische Gesellschaft) has been shaken by a fierce row over an attack on Einstein published last November in Physikalische Blätter, the society's membership journal. Now the editorial board of the society, and the president of the society, Professor Horst Rollnik of the University of Bonn, have dissociated themselves from the original article, by Professor Albrecht Unsold of the University of Kiel. In a statement in the March issue of Physikalische Blätter, they say that Unsold's article contains statements that are open to misinterpretation, or even false, and promise that the journal will carry an article by an historian of science dealing with Einstein's links with Germany. There is, however, no suggestion that the journal will publish the critical letters it has received in the past few months.

Unsold, a theoretician now 75, appears to have begun his attack on Einstein at a symposium held at the University of last May, when he said that Einstein (and Haber) was guilty of crimes "no less serious than those of Hitler".

Unsold says that Einsten's earliest papers were deficient in references to the work of other physicists because of his "narcissism". Unsold says that Einstein had run out of new ideas by the age of 45 , for which reason he turned his attention to public affairs and in particular to "Jewish nationalism", put on a par with the attachment of other physicists (Lenard, Stark and Wien, for example) to German nationalism. The article says that Einsten's move to Berlin in 1914 was motivated by his "enormous salary demands", and that he was frustrated at not being awarded a Nobel Prize sooner because he needed the prize "in order to divorce his first wife".

The article also says that Einstein travelled outside Germany with increasing frequency after 1920 "to fill the emptiness created by the drying up of his more profound ideas" and to "make propaganda" for the theory of relativity and for the creation of the state of Israel. Unsold says that Einstein should have foreseen that his letter to President Roosevelt in 1939, confirming the opinion that nuclear weapons could be built, would lead to the destruction of Hiroshima and Nagasaki. He goes on to urge sympathy for those physicists who stayed behind in Germany after the arrival of Hitler, and who were able to resist the penetration of university faculties by "party personalities" while safeguarding the traditions of research and the university libraries.

There has been a torrent of protests against the publication of Unsold's article, especially from German physicists working abroad. Unsöld has been charged with antisemitism and with mischievous inaccuracy. In reply to one of these complaints, Professor Rollnik explained that he had not seen the article before publication, that its appearance could be accounted for only by a "gross failure" of coordination between the editorial board of the journal (appointed only in 1980) and the editorial staff and that new rules have been devised to prevent the repetition of "such a nasty event".

The disclaimer now published in the March issue of Physikalische Blätter says that the journal must be free to publish controversial opinions even when most members of the society disagree, but that Unsold's article is inaccurate and that its author has only harmed himself in his attempt to defend physicists who worked in Germany during the Third Reich. It remains to be seen whether it will suffice to bring the row to an end. 